\title{
Tingkat Pengetahuan Pasien Rawat Jalan Tentang Penggunaan Antibiotika di Puskesmas Wilayah Karanganyar
}

\author{
Mahardhika A.C. Dewi ${ }^{1}$ dan Yeni Farida ${ }^{1} *$ \\ ${ }^{1}$ Prodi Farmasi, Fakultas Matematika dan Ilmu Pengetahuan Alam, Universitas Sebelas Maret \\ *email korespondensi : yenifarida@staff.uns.ac.id
}

\begin{abstract}
Abstrak: Kurangnya pengetahuan masyarakat tentang antibiotik merupakan faktor resiko meningkatnya tingkat resistensi bakteri terhadap antibiotik. Penelitian ini bertujuan untuk mengetahui gambaran tingkat pengetahuan pasien rawat jalan tentang penggunaan antibiotika di wilayah kota dan pinggiran Karanganyar, serta untuk mengetahui hubungan tingkat pendidikan dengan tingkat pengetahuan responden. Penelitian yang dilakukan merupakan penelitian analitik non eksperimental dengan desain penelitian Cross-Sectional Study. Sampel diperoleh menggunakan metode accidental sampling. Data penelitian diperoleh dari kuesioner diisi oleh 225 pasien rawat jalan di Puskesmas Ngargoyoso dan 281 pasien rawat jalan di Puskesmas Karanganyar. Data yang diperoleh dikelompokkan menjadi data karakteristik pasien terutama tingkat pendidikan (diukur dengan Chi Square) dan data pengetahuan (diukur dengan karakterisasi). Hasil penelitian menunjukkan bahwa di kedua Puskesmas Wilayah Karanganyar memiliki tingkat pengetahuan yang tinggi yaitu $>75 \%$ (Puskesmas Ngargoyoso sebanyak 76,4\% (172 orang) dan di Puskesmas Karanganyar sebanyak 81,8\% (230 orang) mempunyai pengetahuan tinggi). Hasil analisis menggunakan Chi-Square menunjukkan bahwa di kedua lokasi (Puskesmas Karanganyar dan Puskesmas Ngargoyoso) terdapat hubungan antara tingkat pendidikan responden dengan tingkat pengetahuan responden tentang penggunaan antibiotika ( $\mathrm{p}$ value $<0,05)$. Dari hasil penelitian diketahui bahwa tingkat pengetahuan pasien rawat jalan tentang penggunaan antibiotika di 2 Puskesmas Kabupaten Karanganyar tergolong tinggi.
\end{abstract}

Kata kunci: Penggunaan antibiotik; tingkat pengetahuan; pasien rawat jalan; puskesmas wilayah Karanganyar

Abstract. Level of knowledge of the outpatient on the use of antibiotics public health center (puskesmas) in karanganyar. The lack of public knowledge about antibiotics was a risk factor for the increasing level of bacterial resistance to antibiotics. This research aims to know the description of the level of knowledge of the outpatient on the use of antibiotics in rural and urban public health center in Karanganyar, and to know the correlation between education level of respondent with respondents knowledge level. This research was descriptive non-experimental research with Cross-Sectional approach. Samples were obtained using accidental sampling method. Research data from quesionnaires filled by 225 outpatients in Public Health Center of Ngargoyoso and 281 outpatients in Public Health Center of Karanganyar. The data obtained are grouped into patient characteristics data and knowledge data. The result of the research showed that the respondents level of knowledge is included in a good category. They are $76,4 \%$ (172 
people) in Public Health Center of Ngargoyoso have good knowledge about the usage of antibiotics, $23,2 \%$ (52 people) have a moderate knowledge, and $0,4 \%$ (1 orang) has a low knowledge. In Public Health Center of Karanganyar, 81,8\% (230 orang) have good knowledge, $17,1 \%$ (48 people) with moderate knowledge, and 1,1\% ( 3 orang) with low knowledge. The result of the Chi Square analysis show in 2 location (Public Health Center in Karanganyar and Ngargoyoso) there is a correlation between education level of respondent with respondents knowledge level about antibiotics usage ( $\mathrm{p}$ value $<0,05$ ).

Keywords: antibiotics; level of knowledge; outpatient; Puskesmas in Karanganyar

\section{Pendahuluan}

Antibiotika adalah salah satu obat yang sering disalahgunakan karena sangat mudah didapatkan dan harganya murah (WHO, 2014). Penggunaan antibiotika yang berlebihan dan tidak tepat dapat mengakibatkan masalah kekebalan bakteri terhadap antibiotika (Juwono dan Prayitno, 2003). Beberapa dekade terakhir, kemunculan resistensi menjadi masalah global bagi dunia kesehatan. Studi di Eropa menunjukkan resistensi antibiotika meningkat karena adanya peningkatan konsumsi antibiotika yang didorong oleh pengetahuan masyarakat tentang antibiotika yang kurang memadai serta penggunaan antibiotika yang tidak rasional (Lim dan The, 2012). Berdasarkan data penelitian dari tim AMRIN (Antimicrobial Resistance in Indonesia Pravelence and Prevention) di 2 rumah sakit pendidikan di Indonesia, hanya didapat sebanyak $21 \%$ peresepan antibiotika yang tergolong rasional (Duerink et al, 2008).

Berdasarkan penelitian Ardhany et.al. (2016), tingkat pengetahuan masyarakat Desa Basawang RT 03 Kecamatan Teluk Sampit tentang penggunaan antibiotika sebagai pengobatan pada tahun 2016 termasuk dalam kriteria "Tingkat Pengetahuan Cukup" dengan persentase sebesar 50,33\% (115 responden). Kurangnya pengetahuan masyarakat tentang penggunaan antibiotika ini memperburuk kejadian resistensi antibiotika, cara masyarakat yang mengonsumsi antibiotika tidak rutin dan tidak sampai habis dengan alasan sembuh merupakan faktor pendukung resistensi (Kemenkes, 2011 ; Candra, 2011).

Untuk mengatasi hal tersebut Pemerintah Indonesia menggerakan program rasionalitas penggunaan antibiotika yang didukung di Kabupaten Karanganyar. Penanggulangan resistensi antibiotika dilakukan di unit pelayanan kesehatan seperti Puskesmas dan Rumah Sakit yang sering melakukan peresepan antibiotika. Berdasarkan uraian tersebut mendasari peneliti melakukan studi lebih lanjut mengenai tingkat pengetahuan pasien khususnya pasien rawat jalan tentang penggunaan antibiotika di Puskesmas Karanganyar dan Puskesmas Ngargoyoso. Pemilihan lokasi penelitian didasarkan pada studi pendahuluan di Dinas Kesehatan Karanganyar, diketahui data laporan penggunaan antibiotik non pneumonia di kedua puskesmas masih tinggi.

\section{Bahan dan Metode}

Penelitian yang dilakukan merupakan penelitian analitik non eksperimental dengan desain penelitian cross-sectional. Sampel diperoleh menggunakan metode accidental sampling. Penentuan sampel dilakukan dengan menggunakan rumus Slovin.

$$
\mathrm{n}=\frac{N}{N(d)^{2}+1}
$$

keterangan : n (sampel minimal); $\mathrm{N}$ (populasi); d (nilai presisi 95\% atau sig. 0,05) 
Pengumpulan data dengan menggunakan kuesioner yang diambil dari penelitian sebelumnya (Pulungan, 2010) yang telah dimodifikasi dan telah dilakukan uji validitas \& reliabilitas (25 responden). Data penelitian diperoleh dari kuesioner yang diisi oleh 225 pasien rawat jalan di Puskesmas Ngargoyoso dan 281 pasien rawat jalan Puskesmas Karanganyar. Data yang diperoleh dikategorikan dalam kategori karakteristik responden dan pengetahuan responden. Pada kategori pengetahuan dilakukan skoring data, yaitu untuk jawaban benar diberi nilai 3, jawaban salah diberi nilai 2, dan nilai jawaban tidak tahu diberi nilai 1. Analisis hubungan antara tingkat pendidikan dan tingkat pengetahuan pasien rawat jalan dilakukan dengan program SPSS Statistics 21.0 for Windows menggunakan uji Chi-Square.

\section{Hasil dan Pembahasan}

\subsection{Karakteristik responden}

Responden di kedua Puskesmas didominasi oleh responden berjenis kelamin wanita $(72,9 \%$ di Puskesmas Karanganyar dan 80,9\% di Puskesmas Ngargoyoso), hal ini sesuai dengan data kunjungan pasien rawat jalan yang didominasi oleh wanita. Kelompok usia dalam penelitian ini di Puskesmas Karanganyar didominasi oleh kelompok usia 36-45 tahun (dewasa akhir) dan di Puskesmas Ngargoyoso didominasi kelompok usia 26-35 tahun (dewasa awal). Berdasarkan tabel 1, dapat diketahui bahwa mayoritas pekerjaan di kedua Puskesmas adalah di sektor swasta (38,8\% di Puskesmas Karanganyar dan 48,9\% di Puskesmas Ngargoyoso). Tingkat pendidikan responden di Puskesmas Karanganyar didominasi oleh responden berpendidikan SMA $(38,8 \%)$, sedangkan di Puskesmas Ngargoyoso didominasi oleh responden berpendidikan SMP (36,9\%).

Sumber informasi pasien rawat jalan tentang antibiotika di kedua Puskesmas berasal dari Apoteker/Dokter (75,4\% di Puskesmas Karanganyar dan 88,6\% di Puskesmas Ngargoyoso). Hal ini sesuai dengan pendapat Notoatmodjo (2003), bahwa pengetahuan seseorang dipengaruhi oleh tersedianya fasilitas yang berperan sebagai sumber informasi yang benar dan tepat, contohnya adalah fasilitas pengetahuan dari paramedis dan dari pihak lingkungan maupun media. Di kedua Puskesmas mayoritas tidak pernah menggunakan antibiotika tanpa resep dokter (41\% di Puskesmas Karanganyar dan $43 \%$ di Puskesmas Ngargoyoso), kemudian beberapa responden yang menggunakan antibiotika tanpa resep dokter beralasan untuk digunakan sendiri dan biasanya sudah mengetahui jenis antibiotika yang digunakan. Penggunaan antibiotika tanpa resep dokter yang memiliki persentase cukup banyak ini dapat mengakibatkan timbulnya penggunaan antibiotik secara tidak rasional adalah muncul dan berkembangnya kumankebal antibiotik atau terjadinya resistensi antibiotik. Hal ini mengakibatkan layanan pengobatan menjadi tidak efektif, peningkatan morbiditas maupun mortalitas pasien dan meningkatnya biaya perawatan kesehatan (Brahma, 2012 dan Negara,2014). Di kedua Puskesmas Kab. Karanganyar, jenis antibiotika yang sering digunakan responden adalah Amoksisilin (Golongan Penisilin) sebanyak 78,5\% (Puskesmas Karanganyar) dan 86\% (Puskesmas Ngargoyoso). Hal ini sesuai dengan beberapa laporan - laporan hasil penelitian, antibiotika yang paling banyak dikenal sekaligus dipakai masyarakat baik melalui peresepan maupun tanpa resep adalah Amoksisilin (Awad, et al, 2005; Widayati, et al, 2011). 
Tabel 1. Distribusi frekuensi karakteristik responden $(\mathrm{n}=$ frekuensi; $\%=$ persentase). Persentase dihitung dari jumlah pasien dibagi jumlah total dikalikan $100 \%$

\begin{tabular}{|c|c|c|c|c|}
\hline \multirow[b]{2}{*}{ Jenis Kelamin } & \multicolumn{2}{|c|}{$\begin{array}{l}\text { Puskesmas Karanganyar } \\
\qquad(\mathrm{N}=281)\end{array}$} & \multicolumn{2}{|c|}{$\begin{array}{c}\text { Puskesmas Ngargoyoso } \\
(\mathrm{N}=225)\end{array}$} \\
\hline & $\mathbf{n}$ & $\%$ & $\mathbf{n}$ & $\%$ \\
\hline Pria & 76 & 27,1 & 43 & 19,1 \\
\hline Wanita & 205 & 72,9 & 182 & 80,9 \\
\hline Usia & $\mathbf{n}$ & $\%$ & $\mathbf{n}$ & $\%$ \\
\hline $18-25$ tahun & 68 & 24,2 & 40 & 17,8 \\
\hline $26-35$ tahun & 73 & 26 & 70 & 31,1 \\
\hline $36-45$ tahun & 83 & 29,5 & 59 & 26,2 \\
\hline $46-55$ tahun & 45 & 16 & 39 & 17,3 \\
\hline $56-65$ tahun & 2 & 4,3 & 17 & 7,6 \\
\hline Pekerjaan & $\mathbf{n}$ & $\%$ & $\mathbf{n}$ & $\%$ \\
\hline Sektor Swasta & 109 & 38,8 & 110 & 48,9 \\
\hline Ibu Rumah Tangga & 82 & 29,2 & 86 & 38,2 \\
\hline PNS & 39 & 13,9 & 11 & 4,9 \\
\hline Mahasiswa/Pelajar & 24 & 8,5 & 11 & 4,9 \\
\hline Tidak Tahu & 27 & 9,6 & 7 & 3,1 \\
\hline Pendidikan & $\mathbf{n}$ & $\%$ & $\mathbf{n}$ & $\%$ \\
\hline Tidak Sekolah & 0 & 0 & 2 & 0,9 \\
\hline $\mathrm{SD}$ & 31 & 11 & 63 & 28 \\
\hline SMP & 43 & 15,3 & 83 & 36,9 \\
\hline SMA & 109 & 38,8 & 47 & 20,9 \\
\hline PT & 88 & 31,3 & 20 & 8,9 \\
\hline Tidak Tahu & 10 & 3,6 & 10 & 4,4 \\
\hline Sumber Informasi & $\mathbf{n}$ & $\%$ & $\mathbf{n}$ & $\%$ \\
\hline Media Elektronik/Cetak & 30 & 10 & 13 & 5,7 \\
\hline Saudara/Teman & 44 & 14,6 & 13 & 5,7 \\
\hline Apoteker/Dokter & 227 & 75,4 & 201 & 88,6 \\
\hline Jumlah & 301 & 100 & 227 & 100 \\
\hline $\begin{array}{l}\text { Penggunaan Antibiotika } \\
\text { Tanpa Resep Dokter }\end{array}$ & $\mathbf{n}$ & $\%$ & $\mathbf{n}$ & $\%$ \\
\hline Untuk diri sendiri & 136 & 44,3 & 99 & 40,9 \\
\hline Saudara/Teman & 27 & 8,8 & 22 & 9,1 \\
\hline Lain-Lain & 144 & 46,9 & 121 & 50 \\
\hline Jumlah & 307 & 100 & 242 & 100 \\
\hline $\begin{array}{c}\text { Alasan Penggunaan } \\
\text { Antibiotika Tanpa } \\
\text { Resep Dokter }\end{array}$ & $\mathbf{n}$ & $\%$ & $\mathbf{n}$ & $\%$ \\
\hline Mudah didapatkan & 50 & 15,8 & 56 & 22,5 \\
\hline Murah & 18 & 5,7 & 15 & 6 \\
\hline Sudah tahu jenisnya & 102 & 32,2 & 58 & 23,3 \\
\hline $\begin{array}{l}\text { Tidak pernah membeli } \\
\text { tanpa resep dokter }\end{array}$ & 130 & 41 & 107 & 43 \\
\hline Lain-Lain & 17 & 5,3 & 13 & 5,2 \\
\hline Jumlah & 317 & 100 & 249 & 100 \\
\hline $\begin{array}{l}\text { Jenis Antibiotika yang } \\
\text { Digunakan Responden }\end{array}$ & $\mathbf{n}$ & $\%$ & $\mathbf{n}$ & $\%$ \\
\hline Amoksisilin & 256 & 78,5 & 208 & 86 \\
\hline Ciprofloksasin & 32 & 9,8 & 12 & 5 \\
\hline Tetrasiklin & 8 & 2,5 & 1 & 0,4 \\
\hline Cefadroksil & 16 & 5 & 6 & 2,5 \\
\hline Lain-lain & 14 & 4,2 & 15 & 6,1 \\
\hline Jumlah & 326 & 100 & 242 & 100 \\
\hline
\end{tabular}




\subsection{Gambaran tingkat pengetahuan responden}

Antibiotika adalah zat kimia yang diproduksi oleh fungi dan bakteri yang berkhasiat menghambat atau membunuh kuman dalam toksisitas relatif kecil. Indikasi dari antibiotika yaitu untuk penyakit yang diakibatkan oleh infeksi bakteri, sehingga pemberian antibiotika dianjurkan untuk pasien yang menderita gejala akibat infeksi bakteri (Kemenkes, 2011 ${ }^{\mathrm{a}}$ ). Berdasarkan tabel 2 diketahui tingkat pengetahuan responden tentang indikasi antibiotika di Puskesmas Karanganyar tergolong cukup $(67,6 \%)$ dan di Puskesmas Ngargoyoso tergolong rendah $(43,1$ $\%)$. Contoh penyakit yang membutuhkan antibiotika, rata-rata di kedua lokasi menjawab penyakit batuk dan pilek. Hanya 32,7\% (Karanganyar) dan 13,3\% (Ngargoyoso) yang menjawab contoh penyakit yang membutuhkan antibiotika adalah TB (Tuberkulosis Paru). Sehingga pengetahuan tentang penyakit yang membutuhkan antibiotika di kedua Puskesmas tergolong rendah. Penyakit batuk dan pilek (ISPA Non Pneumonia) merupakan penyakit yang disebabkan oleh virus yang pengobatannya tidak memerlukan antibiotika. Berbeda dengan penyakit TB yang merupakan penyakit yang timbul akibat infeksi dari bakteri Mycobacterium tuberkulosis, sehingga perlu antibiotika. Ketidaktepatan pemilihan terapi pengobatan merupakan faktor penggunaan obat yang irasional, hal ini sering terjadi pada penggunaan antibiotika.

Ketidaktepatan dosis antibiotika berisiko terhadap munculnya resistensi kuman terhadap antibiotika. Sebanyak 99,3\% di Puskesmas Karanganyar dan 100\% di Puskesmas Ngargoyoso menjawab bahwa dosis/cara penggunaan antibiotika sesuai aturan pakai dari dokter, sehingga pengetahuan di kedua Puskesmas dikategorikan tinggi. Resistensi antibiotika timbul oleh cara/durasi penggunaan dan dosis antibiotika yang tidak tepat, sehingga akibat dari pemakaian antibiotika yang berlebih, kurang maupun tidak sesuai indikasi (penyakit akibat virus) $\left(\right.$ Kemenkes, $2011^{\mathrm{a}}$ ). Pengetahuan responden tentang resistensi antibiotika tergolong cukup yaitu 68,3\% di Puskesmas Karanganyar dan 65,3\% di Puskesmas Ngargoyoso. Mengenai durasi penggunaan antibiotika di Puskesmas Karanganyar tergolong mempunyai pengetahuan yang tinggi $(79,7 \%)$ dan di Puskesmas Ngargoyoso tergolong cukup (69,3\%). Durasi penggunaan antibiotika yang tepat adalah sampai obat habis, durasi penggunaan erat kaitannya dengan dosis dan waktu penghentian antibiotika. Penghentian antibiotika yang tepat adalah ketika obat sudah habis, bukan ketika gejala klinis menunjukkan bahwa pasien sudah sembuh. Di kedua lokasi, pengetahuan tentang penghentian antibiotika tergolong cukup yaitu 66,9\% di Puskesmas Karanganyar dan 66,7\% di Puskesmas Ngargoyoso. Sehingga, pada peresepan antibiotika diperlukan informasi bahwa obat harus diminum sampai habis selama satu kurun waktu pengobatan, meskipun gejala klinis sudah mereda/hilang. Pemberian informasi juga harus dijelaskan dengan benar (contoh 4x sehari berarti setiap 6 jam), hal ini sangat penting agar kadar obat berada diatas kadar minimal yang dapat membunuh bakteri (Kemenkes, 2011 ${ }^{\mathrm{a}}$ ).

Membagikan antibiotika atau memberikan sisa/sebagian obat antibiotika yang diresepkan dokter untuk terapi penyakit yang diderita adalah tidak diperbolehkan. Hal ini berhubungan dengan keberhasilan terapi dari antibiotika yang diresepkan, serta berkaitan dengan durasi dan dosis antibiotika yang didapatkan oleh pasien. Berdasarkan tabel 2, dapat diketahui bahwa pengetahuan tentang membagikan antibiotika kepada orang lain di Puskesmas Karanganyar tergolong tinggi (80,1\%) dan cukup di Puskesmas Ngargoyoso (73,3\%). Antibiotika diberikan kepada pasien harus berdasarkan peresepan dokter (Kemenkes, 2011 ${ }^{\mathrm{a}}$ ). Cara mendapatkan antibiotika atas resep dokter akan meminimalkan pengobatan tidak rasional pada suatu penyakit. Pengetahuan di kedua Puskesmas Kabupaten Karanganyar tentang cara mendapatkan antibiotika 
dikategorikan cukup yaitu 57,7\% (Puskesmas Karanganyar) dan 68\% (Puskesmas Ngargoyoso). Cara mendapatkan yang tidak tepat disebabkan tingkat pengetahuan pasien yang kurang. Pengetahuan mengenai isu-isu obat yang dikonsumsi akan mempengaruhi cara seseorang dalam memahami obat yang digunakan (Jose, 2013). Berdasarkan gambaran tingkat pengetahuan responden, rata-rata pengetahuan yang perlu ditingkatkan adalah mengenai contoh penyakit yang membutuhkan antibiotika, durasi pengunaan antibiotika, penghentian antibiotika dan cara memperoleh antibiotika. Sehingga hal ini dapat menjadi evaluasi bagi pelayanan kefarmasian di Puskesmas untuk memberikan informasi lebih lanjut mengenai penggunaan antibiotika.

\subsection{Perbandingan tingkat pengetahuan responden}

Tingkat pengetahuan responden di 2 Puskesmas Kab. Karanganyar termasuk dalam kategori tinggi yaitu 81,8\% (Puskesmas Karanganyar) dan 76,4\% (Puskesmas Ngargoyoso) (Tabel 3). Hasil penelitian ini menunjukkan hasil yang lebih positif dibandingkan penelitian di masyarakat Desa Basawang RT. 03 Kecamatan Teluk Sampit pada tahun 2016, yang diketahui tingkat pengetahuan masyarakat tentang penggunaan antibiotika termasuk kategori cukup yaitu sebanyak 50,33\% (Ardhany et.al, 2016). Angka tersebut menunjukkan bahwa tingkat pengetahuan pasien rawat jalan di Puskesmas Kabupaten Karanganyar sudah baik, namun belum maksimal. Hal ini dapat terlaksana apabila pasien rawat jalan di Puskesmas Kabupaten Karanganyar lebih sering mendapatkan penyuluhan dan pengarahan dari para medis yang berada di Puskesmas mengenai penggunaan antibiotika yang rasional.

\subsection{Hubungan karakteristik responden dengan pengetahuan}

Berdasarkan tabel 4, dengan uji Chi Square dapat diketahui bahwa terdapat hubungan antara tingkat pendidikan, usia dan jenis kelamin responden dengan tingkat pengetahuan responden di Puskesmas Ngargoyoso. Hal tersebut dapat diketahui bahwa nilai $p$ value $<$ nilai $\alpha(0,05)$. Di lokasi kedua (Puskesmas Karanganyar) dapat diketahui bahwa hanya terdapat hubungan antara tingkat pendidikan terhadap tingkat pengetahuan responden. Hal tersebut dapat diketahui bahwa nilai $p$ value < nilai $\alpha(0,05)$. Hal ini sejalan dengan teori Notoatmodjo (2003), semakin tinggi tingkat pendidikan seseorang maka semakin tinggi pula tingkat pengetahuannya. Pada umumnya, seseorang yang berpendidikan tinggi akan mempunyai pengetahuan yang lebih luas daripada seseorang yang berpendidikan rendah. Menurut Nursalam (2008) pekerjaan dilakukan untuk menunjang kebutuhan hidup, hasil dari pekerjaan adalah penghasilan yang secara langsung tidak mempengaruhi tingkat pengetahuan responden, sehingga pekerjaan secara langsung dapat mempengaruhi pengetahuan responden dapat pula tidak, hal ini juga terjadi di dua Puskesmas di wilayah Karanganyar. Menurut Notoatmodjo (2003) usia dapat mempengaruhi tingkat pengetahuan seseorang dikarenakan usia dapat mempengaruhi daya tangkap dan pola pikir dari seseorang. Dapat diketahui bahwa usia dan jenis kelamin di Puskesmas wilayah Karanganyar tidak berhubungan dengan tingkat pengetahuan pasien dikarenakan tingkat pendidikan antara responden berjenis kelamin wanita dan pria seimbang (tidak berbeda jauh), begitu pula pada kelompok umur pasien. 
Tabel 2. Gambaran tingkat pengetahuan responden $(\mathrm{n}=$ frekuensi; $\%=$ persentase; $\mathrm{B}=$ benar; $\mathrm{S}$ $=$ salah). Persentase dihitung dari jumlah pasien dibagi jumlah total dikalikan $100 \%$. Kriteria Pengetahuan = Tinggi : 76\%-100\%; Cukup : 56\%-75\%; Rendah : $<56 \%$

\begin{tabular}{|c|c|c|c|c|}
\hline \multirow[b]{2}{*}{ Indikasi Antibiotika } & \multicolumn{2}{|c|}{$\begin{array}{l}\text { Puskesmas } \\
\text { Karanganyar } \\
(\mathbf{N = 2 8 1 )}\end{array}$} & \multicolumn{2}{|c|}{$\begin{array}{c}\text { Puskesmas } \\
\text { Ngargoyoso }(\mathrm{N}=225)\end{array}$} \\
\hline & $\mathbf{n}$ & $\%$ & $\mathbf{n}$ & $\%$ \\
\hline Penyakit infeksi bakteri & 190 & 67,6 & 97 & 43,1 \\
\hline (B) & 77 & 27,4 & 89 & 39,6 \\
\hline Penurun panas/demam (S) & & & & \\
\hline Tidak Tahu & 14 & 5 & 39 & 17,3 \\
\hline $\begin{array}{c}\text { Contoh Penyakit } \\
\text { Menggunakan } \\
\text { Antibiotika } \\
\end{array}$ & $\mathbf{n}$ & $\%$ & $\mathbf{n}$ & $\%$ \\
\hline $\begin{array}{l}\text { TB (Tuberkulosis Paru) } \\
\text { (B) }\end{array}$ & 92 & 32,7 & 30 & 13,3 \\
\hline Batuk dan Pilek (S) & 159 & 56,6 & 152 & 67,6 \\
\hline Tidak Tahu & 30 & 10,7 & 43 & 19,1 \\
\hline $\begin{array}{c}\text { Dosis/Cara Penggunaan } \\
\text { Antibiotika } \\
\end{array}$ & $\mathbf{n}$ & $\%$ & $\mathbf{n}$ & $\%$ \\
\hline Sesuai aturan pakai (B) & 279 & 99,3 & 225 & 100 \\
\hline Bila ingat $(\mathrm{S})$ & 0 & 0 & 0 & 0 \\
\hline Tidak Tahu & 2 & 0,7 & 0 & 0 \\
\hline Resistensi Antibiotika & $\mathbf{n}$ & $\%$ & $\mathbf{n}$ & $\%$ \\
\hline Kuman menjadi kebal (B) & 192 & 68,3 & 147 & 65,3 \\
\hline $\begin{array}{l}\text { Kuman mudah terbunuh } \\
(\mathrm{S})\end{array}$ & 34 & 12,1 & 9 & 4 \\
\hline Tidak Tahu & 55 & 19,6 & 69 & 30,7 \\
\hline $\begin{array}{c}\text { Durasi Penggunaan } \\
\text { Antibiotika }\end{array}$ & $\mathbf{n}$ & $\%$ & $\mathbf{n}$ & $\%$ \\
\hline Sampai habis (B) & 224 & 79,7 & 156 & 69,3 \\
\hline Tidak sampai habis (S) & 51 & 18,2 & 67 & 29,8 \\
\hline Tidak tahu & 6 & 2,1 & 2 & 0,9 \\
\hline Penghentian Antibiotika & $\mathbf{n}$ & $\%$ & $\mathbf{n}$ & $\%$ \\
\hline Gejala klinis hilang (S) & 81 & 28,8 & 74 & 32,9 \\
\hline Sampai habis (B) & 188 & 66,9 & 150 & 66,7 \\
\hline Tidak tahu & 12 & 4,3 & 1 & 0,4 \\
\hline $\begin{array}{l}\text { Membagi Antibiotika } \\
\text { dengan Orang Lain }\end{array}$ & $\mathbf{n}$ & $\%$ & $\mathbf{n}$ & $\%$ \\
\hline Boleh $(\mathrm{S})$ & 33 & 11,7 & 57 & 25,3 \\
\hline Tidak (B) & 225 & 80,1 & 165 & 73,3 \\
\hline Tidak tahu & 23 & 8,2 & 3 & 1,4 \\
\hline $\begin{array}{c}\text { Cara Mendapatkan } \\
\text { Antibiotika }\end{array}$ & $\mathbf{n}$ & $\%$ & $\mathbf{n}$ & $\%$ \\
\hline Resep dokter (B) & 162 & 57,7 & 155 & 68 \\
\hline Tanpa resep dokter $(\mathrm{S})$ & 90 & 32 & 60 & 26,7 \\
\hline Tidak tahu & 29 & 10,3 & 12 & 5,3 \\
\hline
\end{tabular}


Tabel 3. Distribusi frekuensi tingkat pengetahuan responden

\begin{tabular}{ccccc}
\hline & \multicolumn{2}{c}{$\begin{array}{c}\text { Puskesmas } \\
\text { Karanganyar }\end{array}$} & \multicolumn{2}{c}{$\begin{array}{c}\text { Puskesmas } \\
\text { Ngargoyoso }\end{array}$} \\
\hline $\begin{array}{c}\text { Tingkat } \\
\text { Pengetahuan }\end{array}$ & $\mathbf{n}$ & $\%$ & $\mathbf{n}$ & $\%$ \\
\hline Tinggi $(76-100 \%)$ & 230 & 81,8 & 172 & 76,4 \\
Sedang $(56-75 \%)$ & 48 & 17,1 & 52 & 23,2 \\
Rendah $(<56 \%)$ & 3 & 1,1 & 1 & 0,4 \\
\hline Jumlah & $\mathbf{2 8 1}$ & $\mathbf{1 0 0}$ & $\mathbf{2 2 5}$ & $\mathbf{1 0 0}$ \\
\hline
\end{tabular}

Tabel 4. Distribusi frekuensi hubungan karakteristik responden dengan tingkat pengetahuan responden

\begin{tabular}{|c|c|c|c|c|c|c|c|c|}
\hline \multirow{3}{*}{$\begin{array}{c}\text { Karakteristik } \\
\text { Responden }\end{array}$} & \multicolumn{6}{|c|}{ Tingkat Pengetahuan } & \multicolumn{2}{|c|}{ Signifikansi (p value) } \\
\hline & \multicolumn{3}{|c|}{ Puskesmas Karanganyar } & \multicolumn{3}{|c|}{ Puskesmas Ngargoyoso } & \multirow{2}{*}{$\begin{array}{c}\text { Puskesmas } \\
\text { Karanganyar }\end{array}$} & \multirow{2}{*}{$\begin{array}{l}\text { Puskesmas } \\
\text { Ngargoyose }\end{array}$} \\
\hline & Tinggi & Cukup & Rendah & Tinggi & Cukup & Rendah & & \\
\hline \multicolumn{9}{|l|}{ Jenis Kelamin } \\
\hline Pria & 60 & 14 & 2 & 25 & 17 & 1 & \multirow[t]{2}{*}{0,272} & \multirow[t]{2}{*}{0,002} \\
\hline Perempuan & 170 & 34 & 1 & 147 & 35 & 0 & & \\
\hline \multicolumn{9}{|l|}{ Usia } \\
\hline 18-25 tahun & 62 & 6 & 0 & 30 & 10 & 0 & \multirow{5}{*}{0,166} & \multirow{5}{*}{0,002} \\
\hline 26-35 tahun & 61 & 11 & 1 & 61 & 8 & 0 & & \\
\hline 36-45 tahun & 60 & 22 & 1 & 47 & 13 & 0 & & \\
\hline $46-55$ tahun & 37 & 7 & 1 & 25 & 14 & 0 & & \\
\hline $56-65$ tahun & 10 & 2 & 0 & 9 & 7 & 1 & & \\
\hline \multicolumn{9}{|l|}{ Pekerjaan } \\
\hline IRT & 64 & 18 & 0 & 72 & 14 & 0 & \multirow{5}{*}{$\mathbf{0 , 3 0 1}$} & \multirow{5}{*}{0,429} \\
\hline PNS & 37 & 2 & 0 & 10 & 1 & 0 & & \\
\hline Swasta & 87 & 20 & 2 & 78 & 31 & 1 & & \\
\hline Mahasiswa/Siswa & 20 & 4 & 0 & 8 & 3 & 0 & & \\
\hline Tidak Tahu & 22 & 4 & 1 & 4 & 3 & 0 & & \\
\hline \multicolumn{9}{|l|}{ Pendidikan } \\
\hline Tidak Sekolah & 0 & 0 & 0 & 1 & 0 & 1 & \multirow{6}{*}{$\mathbf{0 , 0 0 3}$} & \multirow{6}{*}{0,0001} \\
\hline SD & 24 & 5 & 2 & 42 & 21 & 0 & & \\
\hline SMP & 28 & 14 & 1 & 64 & 19 & 0 & & \\
\hline SMA & 90 & 19 & 0 & 41 & 6 & 0 & & \\
\hline PT & 80 & 8 & 0 & 17 & 3 & 0 & & \\
\hline Tidak Tahu & 8 & 2 & 0 & 7 & 3 & 0 & & \\
\hline
\end{tabular}

\section{Kesimpulan}

Tingkat pengetahuan pasien rawat jalan tentang penggunaan antibiotika di Puskesmas Ngargoyoso dan di Puskesmas Karanganyar dalam kategori baik yaitu 81,8\% (Puskesmas Karanganyar) dan 76,4\% (Puskesmas Ngargoyoso). Akan tetapi, terdapat beberapa pengetahuan yang dirasa perlu ditingkatkan seperti jenis penyakit apa saja yang perlu membutuhkan 
antibiotika, cara mendapatkan obat antibiotika yang benar, durasi penggunaan obat antibiotika dan waktu penghentian obat antibiotika. Di kedua Puskesmas terdapat hubungan yang signifikan antara tingkat pendidikan responden terhadap tingkat pengetahuan, hal ini dibuktikan bahwa nilai p hasil uji Chi Square $(0,0001$ dan 0,003) < nilai $\alpha(0,05)$.

\section{Ucapan Terimakasih}

Terima kasih kepada Dinas Kesehatan Karanganyar atas data dan arahan yang diberikan untuk mendukung penelitian ini.

\section{Daftar Pustaka}

Ardhany, S.D., Ridha Oktavia Anugrah, dan Yurnida H. 2016. Tingkat Pengetahuan Masyarakat Desa Basawang Kecamatan Teluk Sampit tentang Penggunaan Antibiotik Sebagai Pengobatan Infeksi. Prosiding Rakernas dan Pertemuan Ilmiah Tahunan Ikatan Apoteker Indonesia. e-ISSN : 2541-0474. Universitas Muhammadiyah Palangkaraya.

Awad, A., Eltayeb, I., Matowe, L., Thalib, L. 2005. Self-medication with Antibiotics and Antimalarials in the community of Khartoum State. Sudan. J Pharm Pharmaceut Sci, 8(2):326-331

Brahma, Marak, et al. ( 2012). Rational Use of Drug and Irrational Drug Combination. The Internet Journal of Pharmacologi.Vol 10:1

Candra, A. 2011. Batasi Penggunaan Antibiotik. http://health.kompas.com/read/2011/11/14/05535872/Batasi.Penggunaan.Antibiotik (diakses pada 15 Desember 2014)

Duerink, D.O. et al. 2007. Determinants of carriage of resistant Escherichia coli in the Indonesian population inside and outside hospitals. The Journal of antimicrobial chemotherapy.60(2):377-384

Jose J, Jimmy B, Al Shabani AGMS, Al Shabei GA. 2013. A Study Assessing Public Knowledge, Belief and Behavior of Antibiotic Use in Omani Population. Oman Med J, 28(5): 324-330

Juwono, R. \& Prayitno, A. 2003. Farmasi Klinis : Terapi Antibiotik. Jakarta : Gramedia

Kemenkes ${ }^{\mathrm{a}}$. 2011. Modul Penggunaan Obat Rasional. Jakarta : Direktorat Jendral Bina Kefarmasian dan Alat Kesehatan

Kemenkes $^{\mathrm{b}}$. 2011. Pedoman Umum Penggunaan Antibiotik. Jakarta : Direktorat Jendral Bina Kefarmasian dan Alat Kesehatan

Lim, K.K., dan The, C.C. 2012. A Cross Sectional Study of Public Knowledge and Attitude towards Antibiotics in Putrajaya. Malaysia : Southern Med, mkReview

Negara, K.S. 2014. Analisis Implementasi Kebijakan Penggunaan Antibiotika Rasional Untuk Mencegah Resistensi Antibiotika di RSUP Sanglah Denpasar: Studi Kasus Infeksi Methicillin Resistant Staphylococcus Aureus. Jurnal Administrasi Kebijakan Kesehatan (ARSI). Oktober. 2014

Notoatmodjo, S, 2003. Pendidikan dan Perilaku Kesehatan. Jakarta: P.T Rineka Cipta

Pulungan, S. 2010. Hubungan Tingkat Pengetahuan tentang Antibiotika dan Penggunaannya di Kalangan Mahasiswa Non Medis Universitas Sumatera Utara. Karya Tulis Ilmiah. Jakarta : Universitas Sumatera Utara

WHO. 2014. Drug resistance : Antimicrobial use. World Health Organization Programmes and Projects. http://www.who.int/drugresistance/use/en/(diakses 5 Maret 2014).

Widayati, A., Suryawati, S., de Crespigny, C., Hiller, J.E. 2011. Beliefs About the Use of Nonprescribed Antibiotics Among People in Yogyakarta City. Indonesia: A Qualitative Study Based on the Theory of Planned Behavior. Asia Pac. J. PublicHealth 